\title{
PRODUKSI GLUKOSA DARI BATANG KELAPA SAWIT MELALUI PROSES HIDROLISIS SECARA ENZIMATIS MENGGUNAKAN AMILASE TERMOSTABIL
}

\author{
Yetti Marlida $^{1^{*}, \text { Mirzah }^{1}, \text { Syukri Arief }}{ }^{2}$ dan Khoirul Amru ${ }^{3}$ \\ ${ }^{1}$ Prodi Nutrisi dan Teknologi Pakan, Fakultas Peternakan Universitas Andalas. \\ ${ }^{2}$ Jurusan Kimia, FMIPA, Universitas Andalas \\ ${ }^{3}$ Alumni, Prodi Nutrisi dan Teknologi Pakan Fakultas Peternakan Universitas Andalas. \\ *Coressponding Author: yetti_marlida@faterna.unand.ac.id
}

\begin{abstract}
This study aimed to explore the optimization of the concentration of oil palm trunks and thermostable amylase enzyme preformance produce highest sugar (glucose total and reducing sugars) as well as the degree of polymerization. The design used in this study was a completely randomized design (CRD) factorial using 2 factors: factor A which consists of four levels of amylase enzyme that A1: 250 units / kg, A2: 500 units / kg, A3: 750 units / kg and A4: 1000 units / kg. Factor B is the concentration of oil palm trunk yitu B1: 20\% (200 g / 1 liter) B2: 40\% (400 g / 1 liter) and B3: 60\% (600 g / 1 liter) were repeated 3 times. The results showed that there is a highly significant interaction $(\mathrm{P}<0.01)$ in the levels of amylase enzyme (factor $\mathrm{A}$ ) with the concentration of oil palm trunks (factor B) on reducing sugar, siqnificantly interaction $(\mathrm{P}<0.05)$ on total sugars and degree of polymerization (DP). This research can be concluded that the best treatment at a concentration of $60 \%$ oil palm trunks and levels 250 unit $/ \mathrm{kg}$ of an enzyme concentration that produces of total sugars $7.86 \mathrm{mg} / \mathrm{ml}$, reducing sugar $15.69 \mathrm{mg} / \mathrm{ml}$ and degree of polymerization 0.50
\end{abstract}

Keywords : amilase, total gula, gula pereduksi, derajat polimerisasi.

\section{PENDAHULUAN}

Areal perkebunan kelapa sawit di Indonesia berkembang dengan pesat, dengan laju pertumbuhannya mencapai $11 \%$ per tahun $^{[1]}$. Berdasarkan data Badan Pusat Statistik yang dipaparkan oleh Guritno dan Darmoko (2003) ${ }^{[2]}$, areal perkebunan kelapa sawit tahun 1999 luasnya mencapai 3174 726 hektar dengan total produksi minyak mencapai 6217425 ton. Rata-rata luas areal peremajaan selama kurun waktu tahun 2001-2005 diperkirakan mencapai 32155 hektar per tahun. Pada tahun 2008 luas perkebunan kelapa sawit di Indonesia mencapai \pm 7.007 .876 ha dan total produksi \pm 18.089.503 ton $^{[3]}$. Limbah padat berupa batang atau kayu sawit yang dihasilkan sebesar 2257281 ton per tahun. Terjadinya kenaikan yang signifikan pada kurun waktu 2006-2010, kenaikan areal tanam kelapa sawit yang diremajakan mencapai seluas 89 965 hektar rata-rata per tahunnya. Pada kurun waktu tersebut juga terjadi peningkatan limbah batang kelapa sawit yang dihasilkan. Batang kelapa sawit peremajaan yang dihasilkan mencapai 6 315543 ton per tahunnya.

Tingginya limbah batang kelapa sawit hasil peremajaan yang dihasilkan merupakan salah satu potensi yang besar pula dibidang industri peternakan (sebagai bahan pakan alternatif), maupun dibidang industri lainnya seperti energi alternatif (bioetanol). Pemanfaatan limbah batang kelapa sawit belum mendapatkan perhatian yang khusus dibandingkan limbah lainnya yang sama- 
sama berasal dari perkebunan kelapa sawit seperti bungkil kelapa sawit yang telah dijadikan sebagai pakan alteratif untuk ternak.

Batang kelapa sawit hasil dari limbah agroindustri mengandung kadar serat yaitu hemiselulosa, selulosa dan lignin yang tinggi. Berdasarkan hasil Analisa Laboratorium Gizi Ruminansia (2012) batang kelapa sawit mengandung serat kasar 27,18\%, protein kasar 4,59\%, lemak kasar $1,03 \%$, selulosa $29,41 \%$, hemiselulosa $27,06 \%$, lignin $6,95 \%$ dan silika $1,3 \%$. Hasil evaluasi sifat fisik dan kimia batang kelapa sawit menunjukkan bahwa limbah tersebut berpotensi sebagai sumber energi dan dapat dimanfaatkan sebagai bahan baku industri pati. Pati batang kelapa sawit tersimpan dalam sel-sel parenkim dari jaringan vaskular kasar yang mengandung persentasi lignin yang tinggi. Ekstraksi pati dan sel ini tergolong sulit karena struktur dan kandungan komposisi selnya menghalangi penghancuran vaskular dan sel parenkim [4]. Sehingga perlu dilakukannya pengolahan terlebih dahulu, salah satunya hidrolisis oleh enzim (enzimatis).

Enzim merupakan biomolekul berupa protein yang berfungsi sebagai katalis (senyawa yang mempercepat proses reaksi tanpa habis berekasi) dalam suatu reksi kimia organik. Enzim dapat dihasilkan dari mikroorganisme, antara lain kapang dan bakteri. Bakteri isolat NG2 merupakan gram negatif, berspora dan berbentuk batang. Bakteri NG2 merupakan mikroorganisme termofilik, yang dapat digunakan pada suhu yang tinggi. Bakteri termofilik mampu hidup sacara optimal diatas suhu $45^{\circ} \mathrm{C}$ dengan stuktur protein penyusun enzim yang tetap stabil atau tidak terdenaturasi oleh panas. Mikroorganisme ini tidak hanya bersifat toleran terhadap suhu lingkungannya yang bersifat ekstrim tetapi juga mampu untuk bertahan hidup dan berkembang biak pada suhu yang ekstrim, serta menghasilkan enzim yang termostabil.

Hidrolisis pati dapat dilakukan oleh asam atau enzim. Hidrolisa pati merupakan proses pemecahan molekul amilum menjadi bagian-bagian penyusunnya yang lebih sederhana, seperti glukosa. Proses hidrolisis dipengaruhi oleh beberapa faktor, yaitu: level unit enzim, ukuran partikel, $\mathrm{pH}$, waktu hidrolisis, perbandingan cairan terhadap bahan baku (volume substrat), dan pengadukan ${ }^{[5]}$.

Enzim amilase adalah enzim yang mengkatalis hidrolisis pada ikatan 1-4 glikosidik pada produk pati dengan berat molekul rendah, seperti glukosa, maltosa dan maltotriosa yang berfungsi sebagai pemecah ikatan glikosida 1-4 pada senyawa polimer amilum. Produk yang dihasilkan dari proses hidrolisis pati secara enzimatis yaitu berupa produk gula cair dan padatan. Pengolahan yang dilakukan pada penelitian ini adalah pengolahan secara enzimatis yaitu dengan suplementasi enzim amilase termostabil yang merupakan enzim kompleks yang dapat mendegradasi amilum menjadi glukosa. Berdasarkan uraian diatas penulis tertarik untuk melakukan penelitian produksi gula dari batang kelapa sawit melalui proses hidrolisis secara enzimatis menggunakan amilase termostabil

\section{BAHAN DAN METODE}

\section{Bahan}

Bahan utama yang digunakan dalam penelitian ini adalah batang kelapa sawit berumur 22 tahun (yang telah diserut menggunakan sherudding mesin dengan ukuran sekitar 18- 20 mesh) yang diambil dari daerah Ketaping (Sumatera Barat), larutan $\mathrm{HCl} 0,1 \mathrm{M} \mathrm{pH}$ 2,0, aquades, enzim amilase termostabil dari bakteri NG2, bachteriologi peptone, $\mathrm{MgSO}_{4} \cdot 7 \mathrm{H}_{2} \mathrm{O}, \mathrm{KCl}$, tepung tapioka, Nelson A dan B, phosphomolibdat, Fenol 5\% dan $\mathrm{H}_{2} \mathrm{SO} 4$.

\begin{abstract}
Alat
Peralatan yang digunakan yaitu alat-alat gelas, botol universal, pipet, kompor listrik, gelas piala, sendok, gelas ukur, timbangan analitik, aluminium foil, laminar flow, erlenmeyer, sentrifuge, inkubator, petridish, tabung reaksi, autoklaf, kamera foto digital,
\end{abstract}


spektofotometer, shaker water bath, dan menggunakan kertas TCC.

\section{Metode Penelitian}

Penelitian ini menggunakan Rancangan Acak Lengkap (RAL) pola faktorial menggunakan 2 faktor : faktor A yang terdiri dari unit enzim amilase : $\mathrm{A} 1=250$ Uni $/ \mathrm{kg} ; \mathrm{A} 2=500$ Unit $/ \mathrm{kg} ; \mathrm{A} 3=750$ Unit $/ \mathrm{kg} ; \mathrm{A} 4=1000$ Unit $/ \mathrm{kg}$. Faktor B adalah level batang sawit yaitu: B1: $20 \%=$ $200 \mathrm{gram} / \mathrm{l} ; \mathrm{B} 2: 40 \%=400 \mathrm{gram} / \mathrm{l} ; \mathrm{B} 3$ : $60 \%=600$ gram $/ 1$, yang diulang 3 kali.

\section{Penentuan Gula pereduksi ${ }^{[6]}$}

Metode ini dapat digunakan untuk mengukur kadar gula reduksi dengan menggunakan pereaksi phosphomolibdat dan pereaksi Nelson (larutan Nelson A dan Nelson B). Reaksi warna yang terbentuk dapat menentukan konsentrasi gula dalam sampel dengan mengukur absorbansinya

Sebanyak $1 \mathrm{ml}$ larutan gula hasil hidrolisis dimasukkan ke dalam tabung reaksi dan ditambahkan dengan $1 \mathrm{ml}$ pereaksi Nelson, selanjutnya dipanaskan pada pemanas air mendidih selama 20 menit kemudian didinginkan dalam gelas piala yang berisi air dingin. Setelah dingin ditambahkan $1 \mathrm{ml}$ pereaksi phosphomolibdat dan dikocok sampai semua endapan yang ada larut kembali, selanjutnya ditambahkan $7 \mathrm{ml}$ aquadest. Larutan dipindahkan ke dalam kuvet, absorbans larutan diukur pada panjang gelombang maksimum. Kadar gula invert sampel yang telah diencerkan ditentukan dengan menggunakan persamaan regresi absorbans larutan standar.

\section{Pengujian Total gula ${ }^{[7]}$}

Sebanyak $1 \mathrm{ml}$ larutan hasil hidrolisis di masukanan ke dalam tabung reaksi. Sebanyak $1 \mathrm{ml}$ larutan fenol 5\% ditambahkan ke dalamnya, kemudian dikocok. Lima ml larutan asam sulfat pekat ditambahkan dengan cepat dengan cara menuangkan secara tegak lurus ke permukaan larutan. Biarkan selama 10 menit, kocok lalu tempatkan ke dalam penangas air selama 15 menit. Absorbansi larutan diukur pada panjang gelombang 480 nm. Dibuat pula kurva standar glukosa dengan konsentrasi 5-25 ppm.

\section{Perhitungan Derajat polimerisasi (DP) ${ }^{[7]}$}

Derajat polimerisasi dihitung berdasarkan perbandingan antara total gula dengan gula pereduksi yang dihasilkan.

\section{Analisis Data}

Semua data yang diperoleh dianalisis menggunakan analisis varian (anova) Rancangan Acak Lengkap (RAL) pola faktorial dan perbedaan antar perlakuan diuji dengan Duncans Multiple Range Test (DMRT) menurut Steel dan Torrie $(1995)^{[8]}$.

\section{HASIL DAN PEMBAHASAN}

\section{Pengaruh Perlakuan Terhadap Total Gula}

Data rataan total gula yang dihasilkan setelah batang kelapa sawit direaksikan dengan enzim amilase termostabil dapat dilihat pada Tabel 1 .

Pada Tabel 1 dapat dilihat total gula terendah terdapat pada perlakuan A2B1 (level enzim 500 unit dan konsentrasi batang kelapa sawit 20\%) yaitu 3,51 mg/ml, sedangkan total gula tertinggi terdapat pada perlakuan A1B3 (level enzim 250 unit dan konsentrasi batang kelapa sawit $60 \%$ ) yaitu $7,86 \mathrm{mg} / \mathrm{ml}$. Hasil analisis keragaman menunjukan bahwa perlakuan pada faktor A (level enzim amilase) berpengaruh tidak nyata $(\mathrm{P}>0,05)$, faktor $\mathrm{B}$ (konsentrasi batang kelapa sawit) berpengaruh sangat nyata $(\mathrm{P}<0,01)$ dan terdapat interaksi yang nyata $(\mathrm{P}<0,05)$ antara level enzim amilase dengan konsentrasi batang kelapa sawit terhadap total gula yang dihasilkan.

Setelah dilakukan uji lanjut menggunakan DMRT dapat diketahui bahwa level enzim amilase 250 unit $/ \mathrm{kg}$ dan konsentrasi batang kelapa sawit $60 \%$ (perlakuan A1B3) menghasilkan total gula tertinggi. 
Tabel 1. Rataan total gula produk hidrolisis batang kelapa sawit $(\mathrm{mg} / \mathrm{ml})$

\begin{tabular}{llllll}
\hline B & \multicolumn{2}{l}{ A (Enzim Amilase) } & & \multicolumn{2}{c}{ Rata-rata } \\
\cline { 2 - 5 } $\begin{array}{l}\text { (Batang } \\
\text { Sawit) }\end{array}$ & A1 & A2 & A3 & A4 & \\
\hline B1 & $4,61^{\mathrm{efg}}$ & $3,51^{\mathrm{g}}$ & $4,21^{\mathrm{fg}}$ & $3,71^{\mathrm{fg}}$ & $4,01^{\mathrm{c}}$ \\
B2 & $4,81^{\mathrm{def}}$ & $5,92^{\mathrm{bcd}}$ & $4,77^{\mathrm{def}}$ & $5,50^{\text {cde }}$ & $5,25^{\mathrm{b}}$ \\
B3 & $7,86^{\mathrm{a}}$ & $6,76^{\mathrm{ab}}$ & $5,50^{\mathrm{cde}}$ & $6,25^{\mathrm{bc}}$ & $6,59^{\mathrm{a}}$ \\
\hline Rata-rata & 5,76 & 5,40 & 4,83 & 5,16 & \\
\hline
\end{tabular}

Keterangan: Superskrip huruf kecil yang berbeda menunjukkan pengaruh yang berbeda nyata $(\mathrm{P}<0,05)$.

Perlakuan A1B3 tidak berbeda nyata $(\mathrm{P}>0,05)$ dengan perlakuan $\mathrm{A} 2 \mathrm{~B} 3$, jika dibandingkan dengan perlakuan lainnya dengan menggunakan level enzim yang sama (250 unit $/ \mathrm{kg}$ ) dan konsentrasi batang kelapa sawit $20 \%$ dan $40 \%$ (perlakuan A1B1 dan A1B2) maupun dengan level enzim yang berbeda $(500,750$ dan 1000 unit $/ \mathrm{kg}$ ) dan konsentrasi batang kelapa sawit 20\%, 40\% dan $60 \%$ (perlakuan A2B1, A2B2, A3B1, A3B2, A3B3, A4B1, A4B2 dan A4B3) terlihat pengaruh yang berbeda sangat nyata $(\mathrm{P}<0,01)$.

Hasil penelitian menunjukkan bahwa total gula meningkat seiring dengan peningkatan konsentrasi substrat. Hal ini disebabkan pada substrat yang akan dihidrolisis masih tersedia pati dalam jumlah yang banyak. Namun ketika level enzim dinaikkan terjadi penurunan total gula yang dihasilkan, hal ini terjadi karena sisi aktif enzim telah jenuh sehingga tidak ada lagi substrat yang terhirolisis oleh enzim. Hal ini menunjukkan bahwa konsentrasi batang kelapa sawit dan level enzim menentukan jumlah total gula yang dihasilkan.

Hasil yang diperoleh diperkuat dengan pendapat Lehninger (1990), bahwa pada konsentrasi substrat yang tinggi menyebabkan aktivitas enzim semakin meningkat. Hasil ini jauh lebih kecil dari hidrolisis pati singkong oleh Iman (2006) ${ }^{[9]}$ yaitu dengan total gula $24,17 \mathrm{mg} / \mathrm{ml}$. Lebih kecilnya total gula yang di hasilkan dalam penelitian ini menunjukkan kadar pati yang terkandung dalam substrat batang kelapa sawit lebih kecil pula. Jika dibandingkan dengan penelitian yang sama dengan menggunakan enzim selulase, total gula yang dihasilkan dalam penelitian ini jauh lebih kecil. Hal ini disebabkan kandungan selulosa lebih tinggi dibandingkan kandungan pati yang terkandung pada batang kelapa sawit.

Total gula menunjukkan jumlah karbohidrat yang terkandung dalam hidrolisat, baik senyawa reduktif maupun nonreduktif. Hasil pemotongan rantai molekul pati oleh enzim amilase mengakibatkan jumlah molekul oligosakarida meningkat. Dubois et al. $(1956)^{[10]}$ menyatakan bahwa total gula ditetapkan berdasarkan metode fenol dengan prinsip bahwa gula sederhana, oligosakarida, polisakarida dan turunannya bereaksi dengan fenol dan asam sulfat pekat menghasilkan warna orange.

\section{Pengaruh Perlakuan Terhadap Gula Pereduksi}

Data rataan gula pereduksi yang dihasilkan setelah batang kelapa sawit direaksikan dengan enzim amilase termostabil dapat dilihat pada Tabel 2 .

Pada Tabel 2 dapat diketahui gula pereduksi terendah terdapat pada perlakuan A4B1 (level enzim 1000 unit dan konsentrasi batang kelapa sawit 20\%) yaitu $4,83 \mathrm{mg} / \mathrm{ml}$, sedangkan gula pereduksi tertinggi terdapat pada perlakuan A1B3 (level enzim 250 unit dan konsentrasi batang kelapa sawit 60\%) yaitu 15,69 mg/ml. Hasil analisis keragaman menunjukan bahwa perlakuan pada faktor A (unit enzim amilase) dan faktor B (konsentrasi batang kelapa sawit) 
berpengaruh sangat nyata $(\mathrm{P}<0,01)$. Terdapat interaksi yang sangat nyata $(\mathrm{P}<0,01)$ antara level enzim amilase (faktor A) dengan konsentrasi batang kelapa sawit (faktor B) terhadap gula pereduksi yang dihasilkan.

Setelah dilakukan uji lanjut menggunakan DMRT dapat diketahui bahwa level enzim amilase 250 unit $/ \mathrm{kg}$ dan konsentrasi batang kelapa sawit $60 \%$ (perlakuan A1B3) menghasilkan gula pereduksi tertinggi. Jika dibandingkan dengan perlakuan lainnya menggunakan yang level enzim yang sama (250 unit $/ \mathrm{kg}$ ) dan konsentrasi batang kelapa sawit 20\% dan $40 \%$ (perlakuan A1B1 dan A1B2), maupun dengan level enzim yang berbeda (500, 750 dan 1000 unit $/ \mathrm{kg}$ ) dan konsentrasi batang kelapa sawit $60 \%$ (perlakuan A2B3, A3B3 dan A4B3) terlihat pengaruh yang berbeda sangat nyata $(\mathrm{P}<0.01)$. Begitu juga bila perlakuan A1B3 dibandingkan dengan level enzim yang berbeda (500, 750 dan 1000 unit $/ \mathrm{kg}$ ) dan konsentrasi batang kelapa sawit $20 \%$ dan 40\% (perlakuan A2B1, A2B2, A3B1, A3B2, $\mathrm{A} 4 \mathrm{~B} 1$, dan $\mathrm{A} 4 \mathrm{~B} 2)$ terlihat pengaruh yang berbeda sangat nyata $(\mathrm{P}<0,01)$ terhadap gula pereduksi yang dihasilkan.

Tidak meningkatnya kadar gula pereduksi pada saat konsentrasi enzim dinaikkan diduga karena adanya transglukosidase dalam glukoamilase yang membantu terjadinya reaksi kebalikan. Transglukosidase dapat menurunkan produksi glukosa dengan membentuk oligosakarida dengan ikatan $\alpha$ -
1,6 glikosidik. Oligosakarida ini sangat resisten terhadap hidrolisis sehingga dapat menurunkan kadar glukosa yang diperoleh. Hal ini disebabkan konsentrasi substrat dapat mempengaruhi laju produksi dan aktivitas katalitis enzim. Menurut Yetti $(2001)^{[11]}$, penambahan konsentrasi enzim akan meningkatkan kecepatan reaksi bila substrat tersedia secara berlebih. Namun peningkatan kecepatan reaksi akan semakin menurun untuk setiap penambahan konsentrasi enzim, sehingga kecepatan kinetika enzim telah jenuh dengan substrat dan total gula yang dihasilkan pun menurun.

Hasil penelitian ini sedikit lebih lebih besar dibandingkan dengan hasil gula pereduksi hidrolisis pati singkong oleh Iman (2006) ${ }^{[9]}$ yaitu dengan gula pereduksi tertinggi yaitu $14,85 \mathrm{mg} / \mathrm{ml}$. Jika dibandingkan dengan penelitian yang sama dengan menggunakan enzim selulase, gula pereduksi yang dihasilkan dalam penelitian ini jauh lebih tinggi. Hal menunjukkan bahwa dalam hidrolisis menggunakan enzim amilase kemungkinan degradasi polisakarida pati sangat kecil sedangkan hidrolisis menggunakan enzim selulase kemungkinan degradasi polisakarida non pati seperti selulosa dan hemiselulosa sangat besar. Sehingga tidak seluruh sakarida hasil hidrolisis teranalisa oleh metode fenol. Analisis gula pereduksi dengan metode ini menghasilkan warna jingga. Semakin banyak gula pereduksinya maka warna jingga akan semakin pekat (Apriyantono et al, 1989) ${ }^{[7]}$.

Tabel 2. Rataan gula pereduksi produk hidrolisis batang kelapa sawit $(\mathrm{mg} / \mathrm{ml})$

\begin{tabular}{llllll}
\hline B & \multicolumn{2}{l}{ A (Enzim Amilase) } & \multicolumn{2}{c}{ Rata-rata } \\
\cline { 2 - 4 } \begin{tabular}{l} 
Sawit) \\
\cline { 2 - 4 }
\end{tabular} & A1 & A2 & A3 & A4 & \\
\hline B1 & $6,32^{\mathrm{d}}$ & $5,02^{\mathrm{e}}$ & $4,98^{\mathrm{e}}$ & $4,83^{\mathrm{e}}$ & $5,29^{\mathrm{c}}$ \\
B2 & $8,65^{\mathrm{b}}$ & $9,16^{\mathrm{b}}$ & $7,58^{\mathrm{c}}$ & $6,38^{\mathrm{d}}$ & $7,94^{\mathrm{b}}$ \\
B3 & $15,69^{\mathrm{a}}$ & $6,07^{\mathrm{d}}$ & $6,17^{\mathrm{d}}$ & $6,61^{\mathrm{d}}$ & $8,54^{\mathrm{a}}$ \\
\hline Rata-rata & $10,22^{\mathrm{a}}$ & $6,75^{\mathrm{b}}$ & $6,24^{\mathrm{bc}}$ & $5,94^{\mathrm{c}}$ & \\
\hline
\end{tabular}

Keterangan: Superskrip huruf kecil yang berbeda menunjukkan pengaruh yang berbeda nyata $(\mathrm{P}<0,05)$. 
Tabel 3. Rataan derajat polimerisasi produk hidrolisis batang kelapa sawit

\begin{tabular}{|c|c|c|c|c|c|}
\hline \multirow{2}{*}{$\begin{array}{l}\text { B } \\
\text { (Batang } \\
\text { Sawit) }\end{array}$} & \multicolumn{4}{|c|}{ A (Enzim Amilase) } & \multirow[t]{2}{*}{ Rata-rata } \\
\hline & A1 & $\mathrm{A} 2$ & A3 & A4 & \\
\hline B1 & $0,73^{\text {bcde }}$ & $0,71^{\text {bcde }}$ & $0,84^{\mathrm{bc}}$ & $0,77^{\text {bcd }}$ & $0,76^{\mathrm{ab}}$ \\
\hline B2 & $0,57^{\mathrm{de}}$ & $0,65^{\text {cde }}$ & $0,64^{\text {cde }}$ & $0,87^{\mathrm{abc}}$ & $0,68^{\mathrm{b}}$ \\
\hline B3 & $0,50^{\mathrm{e}}$ & $1,12^{\mathrm{a}}$ & $0,91^{\mathrm{ab}}$ & $0,96^{\mathrm{ab}}$ & $0,87^{\mathrm{a}}$ \\
\hline Rata-rata & $0,60^{\mathrm{b}}$ & $0,83^{\mathrm{a}}$ & $0,80^{\mathrm{a}}$ & $0,87^{\mathrm{a}}$ & - \\
\hline
\end{tabular}

Keterangan: Superskrip huruf kecil yang berbeda menunjukkan pengaruh yang berbeda nyata $(\mathrm{P}<0,05)$.

\section{Pengaruh Perlakuan Terhadap Derajat Polimerisasi}

Data rataan derajat polimerisasi yang dihasilkan setelah batang kelapa sawit direaksikan dengan enzim amilase termostabil yang sesuai dengan perlakuan dapat dilihat pada Tabel 3 .

Pada Tabel 3 dapat diketahui derajat polimerisasi terendah pada perlakuan A1B3 (level enzim 250 unit dan konsentrasi batang kelapa sawit $60 \%$ ) yaitu 0,50 . Derajat polimerisasi tertinggi terdapat pada perlakuan A2B3 (level enzim 500 unit dan konsentrasi batang kelapa sawit 60\%) 1.12 . Hasil analisis keragaman menunjukan bahwa perlakuan pada faktor A (level enzim) memberikan pengaruh tidak nyata $(\mathrm{P}>0,05)$ dan faktor B (konsentrasi batang kelapa sawit) memberikan pengaruh yang nyata $(\mathrm{P}<0,05)$. Terdapat interaksi yang nyata $(\mathrm{P}<0,05)$ antara level enzim dengan konsentrasi batang kelapa sawit terhadap derajat polimerisasi yang dihasilkan. Setelah dilakukan uji lanjut menggunakan DMRT dapat diketahui bahwa level enzim amilase 250 unit $/ \mathrm{kg}$ dan konsentrasi batang kelapa sawit $60 \%$ (perlakuan A1B3) menghasilkan derajat polimerisasi terbaik. Perlakuan A2B3 tidak berbeda nyata $(\mathrm{P}>0,05)$ dengan perlakuan A3B3, A4B3 dan A4B2. Jika dibandingkan dengan perlakuan A1B3 terdapat pengaruh yang berbeda sangat nyata $(\mathrm{P}<0,01)$ terhadap derajat polimerisasi.
Rendahnya nilai derajat polimerisasi menunjukkan rantai polimer dari polisakarida sudah terurai menjadi monomer-monomer. Anggraini (2007) ${ }^{[12]}$, menambahkan nilai derajat polimerisasi yang semakin turun menunjukkan bahwa semakin banyak polisakarida yang terdepolimerisasi menjadi senyawasenyawa dengan rantai yang lebih pendek, dimana derajat polimerisasi merupakan variabel yang terikat, tergantung dari nilai total gula dan gula pereduksi yang dihasilkan. Berdasarkan hasil penelitian terhadap derajat polimerisasi hasil hidrolisis batang kelapa sawit oleh enzim amilase termostabil, maka perlakuan terbaik dalam penelitian ini adalah pada perlakuan yang menghasilkan derajat polimerisasi terendah yaitu pada perlakuan A1B3 (level enzim 250 unit dan konsentrasi batang sawit 60\%) yaitu 0,50. Wurzburg (1989) menambahkan, derajat polimerisasi menunjukkan kisaran jumlah unit monomer dalam suatu molekul. Derajat polimerisasi menunjukkan seberapa besar rantai polisakarida yang merupakan polimer amilum dapat dipecah menjadi monomernya amilosa.

\section{UCAPAN TERIMA KASIH}

Diucapkan terima kasih kepada Kementerian Pendidikan dan Kebudayaan, Direktorat Jenderal Pendidikan Tinggi yang telah mendanai penelitian ini dengan skim 
pendanaan MP3EI pada tahun 2012 dengan nomor kontrak: 212/SP2H/PL/Dit. Litabmas/V/2012. Ucapan yang sama juga disampaikan kepada Mahasiswa dan teknisi Labor Teknologi Industri Pakan yang telah membantu pelaksanaan penelitian ini.

\section{DAFTAR PUSTAKA}

1. Susila RW, Peta perencanaan dan Peluang Investasi pada Regenerasi Perkebunan Kelapa Sawit di Indonesia. Seminar Nasional: Mengantisipasi Regenerasi Pertama Perkebunan Kelapa Sawit di Indonesia 9 -10 April 2003, Bali: Max Havelaar Indonesia Foundation.

2. P. Guritno dan D. Damoko, Teknologi Pemanfaatan Limbah Dari Peremajaan Perkebunan Kelapa Sawit. Seminar Nasional : Mengantisipasi Regenerasi Pertama Perkebunan Kelapa Sawit di Indonesia 9-10 April 2003. Bali : Max Havelaar Indonesia Foundation

3. Departemen Pertanian Republik Indonesia, Badan Pusat Statistik dan Direktorat Jenderal Tanaman Pangan. http://www.deptan.go.id. [2 Agustus 2009].

4. Azemi MN, Dos, AMM, Islam MD, Mymensingh, Mehat N.A, Physicochemical properties of oil palm trunk starch. Starch/Satarke. 51: 293- 301, (1999).

5. E. Purba, Hidrolisis Pati Ubi Kayu (Manihot Esculenta) dan Pati Ubi Jalar (Impomonea batatas) menjadi Glukosa secara Cold Process dengan Acid Fungal Amilase dan
Glukoamilase", Universitas Lampung, Lampung, 2009.

6. B. Sudarmadji, Haryono dan Suhardi, Prosedur Analisa untuk Bahan Makanan dan Pertanian. Liberty, Yogyakarta, 1997.

7. A. Apriyantono, D. Fardiaz, P. Niluh, Sedarnawati, S. Budiyanto, Petunjuk Laboratorium Analisis Pangan, Bogor: IPB Press, 1989.

8. R.G. Steel dan J.H. Torrie, Prinsip dan Prosedur Statistik Pendekatan Biometrik. Edisi II. Terjemahan Bambang Sumantri. PT Gramedia Pustaka Utara, Jakarta, 1995.

9. A. Imam, Produksi Hidrosilat Pati dan Serat Pangan dari Singkong dengan Hidrolisis Asam Klorida, Departemen Industri Pertanian, 2006.

10. M. Dubois, K.A. Gilles, J.K. Hamilton, P.A. Rebers, dan F. Smith F, Colorimetric method for determination of sugar and related substances, J. Anal Chem. 28, (3) : 350-356, (1956).

11. M. Yetti, Isolation and purification of raw starch degrading enzyme from acreomonium. Endopytic fungus and its aplication for glucose production. Disertation of doctoral at University Putra Malaysia. Malaysia, 2001.

12. R.W. Anggraini, Resistant Starch tipe III dan tipe IV pati ganyong (Canna edulis), kentang (Solanum tuberosum), dan kimpul (Xanthosoma violaceum Schott) sebagai prebiotik [skripsi], Bogor: Fakultas Teknologi Pertanian, Institut Pertanian Bogor, 2007. 